only on account of its digestibility but also for its power of dilating the stomach. It contains a considerable quantity of alcohol which is quite capable of causing intoxication, but this alcohol is of snch a digestible character that it does not cause organic disease nor does it demoralise as results from drinking European spirits; on the contrary, it helps to sustain and to invigorate. Certainly alcohol taken in that form, even though the quantity imbibed daily may be large, produces no predisposing tendency to tuberculosis. On the contrary, I think it would materially help in the curative treatment of that disease. The effect it has is greatly to increase the adipose tissue of the body. It is to the consumption of tshwala that the well-known obesity of Kaffir chiefs is due.

In reviewing the vital condition of the Kaffir race some allowance must be made for the fact that every Zulu who arrives at adult age is a "survival of the fittest," the weaklings having been weeded out; but though this secures to a great extent a vigorous people it does not prevent a failure of constitution under unfavourable conditions, with the loss of natural immunity against tubercle which allows the bacillus to grow in the body. During their wild existence they live a life which tends to maintain what selection has started. They have no cities and consequently there is no overcrowding. Their grass huts are about six feet high inside, just enough space for a tall man to stand upright. These are not lasting structures, being often destroyed and renewed-change of site for his residence being a Zulu's commonest recourse for protection: when serious illness has attacked his family, and though he thus acts more from superstitious than hygienic motives the result is alike beneficial. Thus the houses do not become the home of all the disease-producing bacilli which have generation after generation affected the residents, as in the case of the old, disease-sodden dwellings of the poor of Europe. To the Kaffir, poor or rich, his hut is a friend, though it is but a shelter and a place to sleep in. To the poor of Europe their houses are often a deadly enemy.

The lithe, wiry figure of the Indian, clad in his brightcoloured clothing, is a familiar and picturesque object in the Natal landscape. 50,000 British Indians reside in the colony. They have been imported chiefly for field labour and are employed principally in the cultivation of sugar-cane on the coast, but though by far the greater number live there they have spread far into the interior and are to be found in every centre of population from Durban to Bulawayo. They belong to the labouring class in India and are for the most part lowcaste Hindoos. Banyans - that is, Mahomedan traders from Bombay - have also found their way to Natal and many have acquired considerable wealth. Residence in Natal carnses the Hindoo labourer to improve greatly in physique which is especially noticeable in the second generation. This is the result of the climate, the country, and the food, Natal being in all three respects for him a change for the better. The Hindoos are industrious and healthy. Their houses are grass-covered huts, or shanties covered with corrugated iron or the tin of packing-cases. They are almost vegetarians in diet, living principally on rice, mealies, peas, fruit, dried fish, clarified butter, and occasionally a little Hesh-mutton, goat, or fowl. They are by no means a temperate people as far as the consumption of alcohol is concerned. They drink spirits freely, especially rum. They are practically free from tuberculosis in any of its forms. It is an exceptional thing to find an adult suffering from pulmonary tuberculosis, nor do children suffer from it in any other region, and tubercle of the skin is very rare.

Here, then, in Natal are two alien races, Europeans and Indians, differing in habits, customs, and food, from one another and from the native Zulus, but both ir common with the native presenting the same aspect with reference to tuberculosis-almost entire immunity. The open-air life which each race lives seems to be the only common influence they enjoy which could account for it.

If the general hospitals in Natal are visited cases of phthisis will be, indeed, found among European patients, bnt almost invariably these are immigrants, mostly young men and in the last stage of the disease. Latterly the number of such persons visiting the colony in search of health has greatly increased and has caused attention to be paid to the matter by the Government so far that shipping companies have been asked not to give passages to persons in advanced consumption, but otherwise no serious attempt has been made to stop the entry of such cases into Natal. No country, however, will long consent to such an invasion, and if it is not checked and some discretion is not exercised in the selection of cases I feel sure that the colony will follow the example of New Zealand and refuse entry to persins suffering from tuberculosis. The great majority of the persons so suffering who have lately arrived in Natal are not only in a hopeless condition but destitute. Very many go with the hope that, the country being a British colony, they will be able to get employment, but as most are palpable victims of consumption no one will employ them and their failing strength soon makes work impossible. They then pass throngh many stages of hardship, until finally they find their way to the hospitals, where they are permited to remain till their death; but these institutions protest against receiving them as their limited funds are; thus used in the treatment of hopeless cases which they. should never have been called upon to admit. It is generally felt that the maintenance of such cases shculd be a charge on the country of their origin which they shonld never have been permitted to leave. If in the future Natal is to be used as a sanatorium for consumptives destitute. persons must be sent there under some recognised system whereby they will be received and maintained in the colony until they are well enough to support themselves or until the end of their life. The present mode of casting them adrift is both inhuman and impolitic.

\section{THE TREATMENT OF PHTHISIS AS PREVALENT DISEASE IN HOLLAND. ${ }^{\prime}$}

\author{
BY DR. R. DE JOSSELIN DE JONG.
}

WHEN the invitation sent by the committee of organisation of this Congress reached me, as one of the founders and the. secretary of the society for organising sanatoria in Hollandr I was especially glad to be able to accept it because themovement is with us still in course of development, and I was: convinced that for us beginners there could be much to be learnt here on this subject, Allow me, in a few words, as a contribution to a general survey about the organisation of sanatoria in Europe, to relate the state of affairs in Holland.

We must not be looked upon as behind-hand because Holland is among the last of the countries to erect popular sanatoria. This has been caused by the historical succession of opinions as to how phthisis should be con tended with. How long was it not believed that high mountain air was the first essential for a good health resort for consumptives? and to this day many are found who see the strongest therapeutic agency in a mountainous climate, in the influence of higher air. For some vears a home for poor Dutch consumptives has existed in Davos Platz, started by private charity, but the idea that we should build our own sanatoria in the mother country-ourlow-lying Netherlands-has only been conceived in the last few years, after the experience gathered at home and abroad had taught us that the dogma of the mountain air therapy could be abandoned. Dr. Hamoeh, our Nestor and president, Professor Kooyker and Dr. Wynhof, as well as others, have called repeated attention not only to the possibility, but to the urgent necessity, of founding popular sanatoria in our own country. What is being accomplished at Tuselbad, Laubbach, Halle, Rehburg, Bournemouth, Cheltenham, and other places can be accomplished with u.s, while it will be counted an advantage that the patients recover in the same climate in which they became ill. The change from sanatorium to their former life is less great if they have been treated in their own country.

In the beginning of the year 1897 about 20 men united to form a founding committee. Among them were the professors for internal diseases of all the four universities. This council has succeeded in awakening the interests of the country in their plans, and a society has been formed for the erection and provision of popular sanatoria for consumptives in Holland. 70 subdivisions were formed in different parts of the country with about 5000 members. H.M. the QueenMother graciously consented to become the patroness of the society. In the course of the first year 200,000 francs had

1 A paper communicated to the British Congress on Tuberculosis. A paper communicated to the British Congress on
Section II., Medical, including Climatology and Sanatoria. 
been collected and the plans could be drawn up for the first sanatorium. The great question in our country was where the first sanatorium should be--on the sea-coast or in the interior? Professor Kooyker. had already spoken on this subject at the Berlin Congress in 1899, and touched on the difficulties and advantages of both situations. Notwithstanding that, in proportion to the size of the country, our coast-line is a long one, it is very dificult to find a suitable spot for a so-called "seaside sanatorium." 'The exposure to west and north-west winds makes most of the places on the coast unsuitable, especially in winter. We decided to begin with an inland sanatorium, and we believe that we have found an excellent situation, for it in the east of the country -in the province of Overysel. It is, however, still most decidedly our purpose, when we are in a position to build a second sanatorium, to have it on the coast, as we are convinced that the strong, pure sea air will be a mighty power against phthisis; and although this air may not be suitable for more erethic constitutions, for less serious cases and for rorpid tuberculosis it will, without doubt, be of the greatest advantage. This has been sufficiently proved to us by the beneficial effect a stay at the seaside has upon sorofulous children.

There is a second reason why a seaside sanatorium should in time be built in Holland. H.M. the Queen-Mother when whe ceased to be Regent in 1898 presented her estate, OrangeNassau, together with a sum of 250,000 franes, being part of the sum collected by the people for a national memorial in her honour, to found a sanatorium for consumptive patients. Orange-Nassau Oord lies in Gelderland, also in the east of our country, and thus will be an inland sanatorium as well. This establishment is intended for paying patients only. Her Majesty appointed a separate committee of six menbers to manage her sanatorium for her. It will be opened in the course of the next two or three months as well as ours, so that before the end of this year Holland will possess two large sanatoria for consumptives. A third will soon be erected by the city of Amsterdam not far from the coast of the Zuyder Zee.

As I have said, the sanatorium "Hellendoorn," which will be opened in Overysel, and so called after the neighbouring village, bears the character of other continental establishments. It will at first contain 54 beds, but it is intended to enlarge the institution to accommodate 105 patients. It is intended only for poor patients and as much as posisible, that is to say. for as much as the annual contributions will allow, the inmates will be treated gratis. In order to make the number of free patient; as large as possible an attempt will be made to enlaroe the funds by soliciting annual contributions from the Govermment, the various communities, and the industrial insurance societies. The less needy patients will pay a certain fixed sum, about 3. 6d. a day. It is arranger to accommodate both men and women, strictly separated from each other, with special kitchen arrangements for Jews. The principal building is in the shape of a slightly bent half-moon, opening on the south. "The verandahs, where the patients will be in the open air, are in the wings, while the domestic department is on the north side, more or less by itself. The building is sheltered on the west by extensive pine woods and on the north and reast by hills covered with pine woods. A beautiful view to the south and west greatly increases the attractiveness of the place. Electric light and a central heating apparatus are being laid on. The floors are covered with torgament, as is the case at Sulzhaim in Uarz. Tt is rather expensive to put down, but its durability renclers it cheaper in the end. Drinking water of excellent quality has been procured on the spot by boring. More than six patients will not be allowed in one room: generally there will only be four. Within an hour's distance there are no factory chimnevs and no railways, so that there will be no fear that the air will be poisoned by either. The soil is sandy, dry, and porous. have myself been able to prove by experiments in the sand dunes near the Hague that bacteria, among others even the rather vigorous bacillus prodigiosus, are entirely destroyed in a few days in sand, so that for a sanatorium for tuberculous patients this soil is especially suitable. As for the air itself, there are still followers to be found of the doctrine, "No cure without mountain air," but in our country we have ceased to believe this exclusively.

Last year a small private sanatorium was opened near Putten, in Gelderland, on a spot surrounded by pine woods and at about an hour's distance from the Zuyder Zee. The patients were able to be out-of-doors there until nine o'clock, or sometimes even till half-past nine, all the year round, just as well as in Homnef and other places. The results gained there will bear comparison with those gained at foreign sanatoria. The experience gathered has been short, but it does not in any way put our expectations to shame; on the contrary, it gives us reason to expect great things of a sanatorium built after the strictest and newest improvements as that at Hellendoorn will be. 'The patients will be subjected to a very strict rérime analogons to the rules laid down in like forcign sanatoria. And here I venture to remark that the earnestness and perseverance with which the director and the nursing staff impress these rules upon the minds of the patients, inpressing upon them their immense importance, will to a great extent fix the bounds of the useful effect of the sanatorium treatment directly and indirectly. I purposely nse the word "indirectly," because, to my thinking, the indirect influence of a sanatorium is not the least of its influences.

A sanatoriun for consumptives must have two useful effects: (1) the improvement of the health of the patients admitted-this is a matter of course; and (2) it must be a centre from which good and clear ideas on the subject of hygiene are constantly being spread amongst the poor and less intellectual classes. The discharged patients must be so imbued witz the value of good fresh air, simple but nutritious food, a quiet, even mode of life, cleanliness of their homes as well as of their persons, and so on, that upon their return to their former life they may become the teachers of hygiene to those about them. The experience which I have had in this way, in only a few years, from different patients treated in Davos-Platz is really surprising. The patients receive a printed list of the rules which they have to keep, together with a number of useful hints which may be of benefit to them in their future life.

I cannot leave this subject without saving a few worls on two points which belong to it, and which seem to me to be of the greatest importance. If the treatment in a sanatorium is to have the good and lasting effect that is to be expected, it is absolutely necessary that if the patient admitted is the brearl-winner of a family (as is often the case), provision should be made for the remaining needy members of the family. The board of our society have thencfore urged the sub-committees to take care that in such cases assistance is rendered to those left behind. This will relieve and cheer the mind of the patient, and have a good influence towards his or her recovery.

In the second place, care must be taken that what has been gained in the samatorium is not lost as soon as the discharged patients return to their own unhealthy surroundings. In other worls, the improvement of the houses of the working-classes should keep step with the erection of sanatoria. In dry, well-ventilated. healthy working-men's homes the entirely or partially cured patient will be able to continue in the hygienic rules of life which he began in the sanatorium, and the results gained will remain or even be improved upon. It seems to me that this is one of the most weighty points which can arise in a discussion about the benefit of sanatorium treatment. In our country various private parties are doing much in this direction. The well-known Agnetapark in Delft can be quoted as an example.

As it is especially desirable that only those patients should be admitted who are in a not too far advanced stage of the disease the application must be made by the family physician with the additional advice of a specially appointed medical man. There will be 20 of these consulting physicians appointed in different parts of the country. After their application the medical director must decide whether or not the patients can be admitted. By these means we in time hope to be able to show results which can equal any of those obtained in foreign sanatoria.

The Proposed Sanatorium for Consumptives AT WINSLEY.-At the Victoria-rooms, Clifton, an influential meeting has been held in support of the proposed sanatorium for consumptives at Winsley, near Bradford-on-Avon. The Lord Mayor presided and amongst those present were the Bishop of Bristol, Dr. P. H. Pye-Smith of Guy's Hospital, Dr. Long Fox, Dr. L. A. Weatherly, Dr. Mar'sham Skerritt, and Dr. Shingleton Smith. The Lord Mayor made an appeal for help from Bristol citizens and stated that Bristol will be allotted 15 beds out of the 60 to be provided. 